\title{
A review of sleep deprivation studies evaluating the brain transcriptome
}

\author{
Alisa S Elliott ${ }^{1}$, Jason D Huber ${ }^{2}$, James P O'Callaghan ${ }^{3}$, Charles L Rosen ${ }^{1}$ and Diane B Miller ${ }^{3^{*}}$
}

\begin{abstract}
Epidemiological studies show a positive association between adequate sleep and good health. Further, disrupted sleep may increase the risk for CNS diseases, such as stroke and Alzheimer's disease. However, there has been limited progress in determining how sleep is linked to brain health or how sleep disruption may increase susceptibility to brain insult and disease. Animal studies can aid in understanding these links. In reviewing the animal literature related to the effects of sleep disruption on the brain, we found most of the work was directed toward investigating and characterizing the role of various brain areas or structures in initiating and regulating sleep. In contrast, limited effort has been directed towards understanding how sleep disruption alters the brain's health or susceptibility to insult. We also note many current studies have determined the changes in the brain following compromised sleep by examining, for example, the brain transcriptome or to a more limited extent the proteome. However, these studies have utilized almost exclusively total sleep deprivation (e.g., 24 out of 24 hours) paradigms or single short periods of limited acute sleep deprivation (e.g., 3 out of 24 hours). While such strategies are beneficial in understanding how sleep is controlled, they may not have much translational value for determining links between sleep and brain health or for determining how sleep disruption may increase brain susceptibility to insult. Surprisingly, few studies have determined how the duration and recurrence of sleep deprivation influence the effects seen after sleep deprivation. Our aim in this review was to identify relevant rodent studies from 1980 through 2012 and analyze those that use varying durations of sleep deprivation or restriction in their effort to evaluate the effects of sleep deprivation on the brain transcriptome and to a more limited extent the proteome. We examined how differences in the duration of sleep deprivation affect gene and protein expression to better understand the full consequences of repeated sleep disruption on the brain. Future research needs to consider and emphasize how the type and extent of the sleep deprivation exposure impacts the conclusions reached concerning the influence of sleep disruption on the brain.

We identified relevant studies between 1980 and 2012 by searching the electronic databases of PubMed, Medline (Ovid), Embase (Ovid), and Web of Science using the terms "sleep" AND "disrupt", "deprivation", "restrict", "fragment", "loss", "disturb", "disorder", "dysfunction", "brain", "cortex", striatum", hypothalamus", "hippocampus", "gene", "protein", "genomics", "proteomics", "polymerase chain reaction", "pcr", "microarray", "molecular", "rodent" "rat", "rats", "mouse", "mice". All searches were limited to rodent studies in English and the reference lists of retrieved articles were searched for additional pertinent studies.
\end{abstract}

Keywords: Sleep deprivation; Transcriptome; Sleep disruption; Rodent

\footnotetext{
* Correspondence: dum6@cdc.gov

${ }^{3}$ Toxicology and Molecular Biology Branch, CDC-NIOSH, 1095 Willowdale Rd., Morgantown, WV 26505, USA

Full list of author information is available at the end of the article
}

\section{Springer}

(c) 2014 Elliott et al.; licensee Springer. This is an Open Access article distributed under the terms of the Creative Commons Attribution License (http://creativecommons.org/licenses/by/4.0), which permits unrestricted use, distribution, and reproduction in any medium, provided the original work is properly credited. 


\section{Introduction}

Sleep, one of the most conserved behaviors, consumes approximately one third of a person's life, yet the purpose of sleep is still not fully understood. In an effort to understand the function of sleep, researchers predominately study the effects of sleep deprivation (SD) and sleep restriction (SR) in humans and animals. Initially, increased sleepiness was thought to be the main consequence of sleep loss and its presence accounted for the various effects of sleep loss such as cognitive impairment. Consequently, researchers did not focus on the possible short and long-term pathophysiological consequences of sleep loss that could impact overall health (Kushida 2006). Much of the early emphasis was on neurobehavioral recovery following sleep loss and ways to treat and hasten recovery (Kushida 2006; Lamond et al. 2007). More recently, epidemiological studies have suggested that a person's overall health is influenced by sleep patterns throughout life, with a positive association seen between shortened sleep duration and morbidity and mortality (Qureshi et al. 1997; Ayas et al. 2003; Ferrie et al. 2007; Ikehara et al. 2009; Luyster et al. 2012). People who report habitually short sleep durations, defined as sleep durations less than six hours each night, have an increased prevalence of type 2 diabetes, hypertension, obesity, cardiovascular disease, and stroke (Qureshi et al. 1997; Ayas et al. 2003; Schultes et al. 2005; Spiegel et al. 2005; Gottlieb et al. 2006; Ferrie et al. 2007; Cappuccio et al. 2008; Chen et al. 2008; Ikehara et al. 2009; Kim and Jo 2010; Sabanayagam and Shankar 2010; Luyster et al. 2012; Chaput et al. 2007). Further, a study in Finland found that workers engaged in shift work (SW), that is, work outside regular daytime hours, had a higher incidence of stroke suggesting some aspect of shift work increases the vulnerability of the brain (Nurminen and Karjalainen 2001). Disrupted sleep is often a byproduct of SW resulting in shift workers being more likely to have shorter sleep durations than people who work regular daytime hours (Luckhaupt et al. 2010). According to the 2010 National Health Interview Survey (NHIS), over 40 million employed U.S. adults report habitually short sleep durations. Furthermore, the American Academy of Sleep Medicine and the Sleep Research Society define this the prolonged state of shortened or mistimed sleep as chronic sleep deficiency and recently reported their concern for its increase in the population and the probable negative health outcomes as a result (Luyster et al. 2012). Despite the increasing research emphasis on understanding sleep unfortunately the function of sleep remains elusive. Although, adequate sleep appears to be necessary for good health the relationship(s) between sleep and health remain unclear and difficult to objectively measure.

Cognitive impairment due to sustained wakefulness or SR has been the focus of much research in the sleep research arena. Many studies, including dose-response studies have evaluated the cumulative build-up of cognitive performance deficits with extended SD or SR (Van Dongen et al. 2003). Despite the advances in determining the cognitive consequences of insufficient sleep the physiological function of sleep is still not well characterized or understood. Advancement over the last 20 years in "omics" methods, such as transcriptomics utilizing realtime polymerase chain reaction (PCR) and cDNA microarrays, as well as proteomics to a lesser extent has aided in a better understanding of the differences between sleep, waking, and sleep deprived states at the molecular level. Many studies demonstrate differences in the molecular characteristics of brain following various forms of sleep disruption. Microarrays, specifically, have become widely used in sleep research to evaluate and compare transcriptomic profiles of sleep-wake and sleep deprived states with an initial emphasis on characterizing the sleep and awake states. Together, these studies have yielded thousands of candidate genes involved in sleep homeostasis and/or function (Terao et al. 2003a; Terao et al. 2003b; Cirelli et al. 2006; Terao et al. 2006; Mackiewicz et al. 2007; Maret et al. 2007; Kilduff et al. 2008; Mackiewicz et al. 2009; Thompson et al. 2010; Veasey 2010; Datta et al. 2011; Mongrain et al. 2011). Many of these genes are now considered sleep-state regulated and belong to classes of genes involved in specific cellular functions, such as synaptic maintenance and plasticity (Taishi et al. 2001; Nelson et al. 2004; Maret et al. 2007; Das et al. 2008; Mallick and Singh 2011; Tadavarty et al. 2011; Franco-Perez et al. 2012; Singh et al. 2012; Volkow et al. 2012), metabolism (Basheer et al. 2001; Kong et al. 2002; Mackiewicz et al. 2003; Nikonova et al. 2010; Petit et al. 2010; Everson and Szabo 2011; Martins et al. 2011; Barf et al. 2012), stress response (Meerlo et al. 2002; Terao et al. 2003b; Sgoifo et al. 2006; Brown and Naidoo 2010; Kalinchuk et al. 2010), and neuroprotection (Weil et al. 2009; Mongrain et al. 2010; Dattilo et al. 2011; Wisor et al. 2011). From this research, several theories of the physiological function of sleep have developed that have the potential to begin to explain the link between sleep habit and overall health. It is important to note, however, that many of these studies only looked at the molecular consequences of the sleep state after one episode of short-term sleep deprivation. How the duration and frequency of sleep deprivation influences the outcome has received little attention as factors important to consider, especially when analyzing and interpreting the results. Evaluating the data from the studies in a durationdependent construct will provide insight into how the brain reacts to sleep deprivation as it cumulates. Therefore, this review aims to analyze the existing literature on sleep deprivation's effect on the transcriptome by using duration of sleep deprivation as the chief independent variable. Although the review concentrates on the impact 
of sleep deprivation on the brain transcriptome, proteomic studies are included when warranted. To begin the data sources and study selection criteria are described and followed by a brief background on methods used to identify and assess sleep.

\section{Data sources and study selection}

An extensive search of the electronic databases of PubMed, Medline, Embase, and Web of Science was conducted to identify animal studies (1980-2012) that assessed the effects of SD on gene and protein expression in the brain. The terms "sleep" AND "disrupt", "deprivation", "restrict", "fragment", "loss", "disturb", "disorder", "dysfunction", "brain", "cortex", striatum", hypothalamus", "hippocampus", "gene", "protein", "genomics", "proteomics", "polymerase chain reaction", "pcr", "microarray", "molecular", "rodent" "rat", "rats", "mouse", "mice" were used in the searches. The reference lists of included studies were also searched for pertinent papers. The first and last author determined the inclusion/exclusion criteria. The animal studies were limited to rat and mouse studies for easier generalizability across studies. All methods utilized to cause SD were included. However, studies modeling sleep disorders, such as sleep apnea and insomnia, were excluded. Furthermore, gene expression needed to be determined for multiple, not single, genes in order to provide a more complete profile of the SD transcriptome. Any paper investigating the impact of sleep on a brain region was accepted, but cortex became the focal point since it was the region of interest in the majority of studies. Publication dates for the searches ranged from 1980 to July 2012, and all searches were restricted to English.

\section{Identifying and assessing sleep}

Sleep is widely defined as a rapidly reversible state of greatly reduced responsiveness and immobility (Siegel 2005; Allada and Siegel 2008). The advent of the electroencephalogram (EEG) signify the beginning of modern sleep research. By placing electrodes on the scalp, the EEG records the voltage changes produced by ionic currents within the thousands of neurons in the cerebral cortex. The voltage changes are recorded continuously, resulting in data in the form of a wave. Wave profiles, determined by the wave's amplitude and frequency, reflect neuronal activity and correspond with levels of consciousness, including stages, or depth, of sleep. EEG recordings can be used in mammals as a way to identify sleep and its various stages.

More recently, a set of distinct behaviors has become accepted for defining sleep given the difficulty of transplanting electrodes to record EEGs in many species. One behavior required is reduced motor activity and is usually accompanied by a species-specific sleep posture. A second recognized sleep behavior is a reduced or total lack of response to stimuli during sleep that regularly evokes a response when awake. Thirdly, sufficient stimuli should cause the rapid reversal from sleep to wake states. The ability to quickly reverse back to the wake state is important as it differentiates sleep from coma. Finally, a balance between sleep and wake states, termed sleep homeostasis, needs to be apparent. The existence of sleep homeostasis is supported by the presence of sleep propensity and recovery sleep. Sleep propensity, also termed sleepiness, is the likelihood of an individual to fall asleep. Sleep propensity increases as wakefulness continues. Recovery sleep is the longer and deeper sleep that occurs after SD. A species exhibiting all these behaviors are considered to have sleep-like states. By including behavior criteria to identify sleep, researchers have been able to identify several other species that engage in sleep-like states, such as the fruit fly Drosophila melanogaster (Hendricks et al. 2000; Shaw et al. 2000), zebra fish Danio rerio (Zhdanova et al. 2001; Yokogawa et al. 2007), and roundworm Caenorhabditis elegans (Van Buskirk and Sternberg 2007; Raizen et al. 2008).

Sleep function and homeostasis are primarily investigated through SD studies where various techniques are implemented in an attempt to prevent the animal from sleeping (Table 1). For instance, some SD techniques place the rodent on a constantly rotating drum or platform ("disk-over-water" or DOW) where the animal must continuously walk to avoid water and cannot sleep (Rechtschaffen et al. 1999; Coenen and van Luijtelaar 1985). Less physically demanding methods place the rodent inside an automated running wheel or on a platform ("moving platform") that is activated at sleep onset via EEG monitoring (Fenzl et al. 2007). The gentle handling method, where the rodent is lightly prodded or brushed when sleep is observed, is considered to be one of the least stressful methods and reduces the amount of physical activity required of the rodent (Fenzl et al. 2007). Unfortunately, this method is not automated and can be taxing on the researcher when implemented for long periods of time. Consequently, gentle handling is usually only used for short term (i.e., acute) SD studies of 8 hours or less. Each technique introduces its own set of extraneous variables into the study and the reader should know that although these methods can produce a substantial amount of sleep deprivation none of these result in total SD. Even the EEG monitoring methods have some "lag-time" between the recognition of a sleep state and waking the animal. Further, sleep processes such as microsleeps, local sleep, increased hippocampal spike rates and increases in the EEG recording amplitude can intrude during the deprivation period even though the procedures are successful in keeping animals awake for a large period of time (Friedman et al. 1979; Vyazovskiy et al. 2011). For example, EEG monitoring of rats deprived 
Table 1 Studies evaluating the consequences of sleep deprivation on the brain

\begin{tabular}{|c|c|c|c|c|c|c|c|}
\hline Reference & SD method & Conditions & Species; sex & Age & Time of sacrifice* & Expression method & Brain area \\
\hline $\begin{array}{l}\text { Naidoo N. et al., } 2005 . \\
\text { (Naidoo et al. 2005) }\end{array}$ & Gentle handling & $\begin{array}{l}3 \mathrm{~h}, 6 \mathrm{~h}, 9 \mathrm{~h} \text { and } 12 \mathrm{~h} \mathrm{SD}- \\
\text { beginning at lights-on }\end{array}$ & 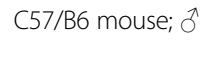 & 10 weeks & Immediately after SD & WB & CTX \\
\hline $\begin{array}{l}\text { Maret S. et al., 2007. } \\
\text { (Maret et al. 2007) }\end{array}$ & Gentle handling & $\begin{array}{l}6 \mathrm{~h} \mathrm{SD} \text { - beginning at } \\
\text { multiple time points }\end{array}$ & $\begin{array}{l}\text { C57BL/6 J; AKR/J; } \\
\text { DBA/2 J Mouse; } \tilde{O}^{\wedge}\end{array}$ & 12-13 weeks & During last $30 \mathrm{~min}$ of SD & $\mathrm{MA}, \mathrm{QPCR}$ & Whole Brain \\
\hline $\begin{array}{l}\text { Conti B. et al., 2007. } \\
\text { (Conti et al. 2007) }\end{array}$ & Gentle handling & 24 hours SD & $\begin{array}{l}\text { Sprague-Dawley } \\
\text { rats; } \hat{0}\end{array}$ & Adult (250-300 g) & Immediately after SD & MA & $\begin{array}{l}\text { PFC, FCTX, AMY, } \\
\text { HYPO, HIPP, DRN, } \\
\text { LC }\end{array}$ \\
\hline $\begin{array}{l}\text { Thompson C. et al., 2010. } \\
\text { (Thompson et al. 2010) }\end{array}$ & Gentle handling & $\begin{array}{l}6 \mathrm{~h} \mathrm{SD} ; 4 \mathrm{~h} \text { RS after } \\
6 \mathrm{~h} \mathrm{SD}-\text { beginning at } \\
\text { lights-on }\end{array}$ & C57BL/6 J mouse; $\widehat{0}$ & 9-11 week & Immediately after SD or RS & $\mathrm{MA}, \mathrm{ISH}$ & $\begin{array}{l}\text { ORB, SCN, HCRT, } \\
\text { TMN, PMCO, ENT, } \\
\text { LC }\end{array}$ \\
\hline $\begin{array}{l}\text { Cirelli C. and Tononi G., } 1999 . \\
\text { (Cirelli and Tononi 1999b) }\end{array}$ & & $\begin{array}{l}3 \text { h SD; } 3 \text { h spontaneously } \\
\text { asleep (S); } 3 \text { h spontaneously } \\
\text { awake (W) }\end{array}$ & $\begin{array}{l}\text { Wistar Kyoto (WKY) } \\
\text { rats; } \hat{O}^{-}\end{array}$ & & & MA & CTX \\
\hline $\begin{array}{l}\text { Cirelli C. et al., } 2004 . \\
\text { (Cirelli et al. 2004) }\end{array}$ & Gentle handling & $\begin{array}{l}8 \mathrm{~h} \text { SD - beginning at lights-on; } \\
\text { spontaneously asleep (S); } \\
\text { spontaneously awake (M) }\end{array}$ & WKY rats; $\widehat{\partial}$ & & $\begin{array}{l}\text { Immediately after SD, } \\
6 \text { am for W rats }\end{array}$ & $\begin{array}{l}\text { Microarray (pooled } \\
\text { samples); real-time } \\
\text { qPCR (pooled samples) }\end{array}$ & CTX \\
\hline $\begin{array}{l}\text { Cirelli C et al., 2006. } \\
\text { (Cirelli et al. 2006) }\end{array}$ & $\begin{array}{l}\text { Gentle handling for } \\
\text { s-SD; DOW for I-SD }\end{array}$ & $\begin{array}{l}8 \mathrm{~h} \mathrm{SD}(\mathrm{s}-\mathrm{SD}) \text { - beginning at } \\
\text { lights-on; 7d SD (I-SD) }\end{array}$ & WKY rats; $\hat{o}$ & Adult (300-450 g) & Immediately after SD & $M A, Q P C R$ & CTX \\
\hline $\begin{array}{l}\text { Mackiewicz M., et al., } 2007 . \\
\text { (Mackiewicz et al. 2007) }\end{array}$ & Gentle handling & $\begin{array}{l}3 \mathrm{~h}, 6 \mathrm{~h}, 9 \mathrm{~h} \text { and } 12 \mathrm{~h} \mathrm{SD}- \\
\text { beginning at lights-on }\end{array}$ & C57BL/6 J mice; $\widehat{O}$ & 10-12 weeks & Immediately after SD & MA & CTX, HYPO \\
\hline $\begin{array}{l}\text { Nikonova E., et al., 2010. } \\
\text { (Nikonova et al. 2010) }\end{array}$ & Gentle handling & $\begin{array}{l}\text { h3 and } 12 \mathrm{~h} \text { SD - beginning } \\
\text { at lights-on }\end{array}$ & C57BL/6 J mice; $0 \hat{}$ & 8-10 weeks & Immediately after SD & WB, QPCR & CTX \\
\hline $\begin{array}{l}\text { Terao A., et al., } 2003 . \\
\text { (Terao et al. 2003a) }\end{array}$ & Gentle handling & $\begin{array}{l}6 \mathrm{~h} \text { SD; } 4 \mathrm{~h} \text { RS after } 6 \mathrm{~h} \text { SD - } \\
\text { beginning at lights-on }\end{array}$ & C57BL/6 J mice; 01 & 10-12 weeks & Immediately after SD or RS & WB, QPCR & $\begin{array}{l}\mathrm{BF}, \mathrm{TH}, \mathrm{HYPO}, \mathrm{CTX} \\
\mathrm{CB}, \mathrm{P}, \mathrm{MD}\end{array}$ \\
\hline $\begin{array}{l}\text { Cirelli C. and Tononi G., } 2000 . \\
\text { (Cirelli and Tononi 2000a) }\end{array}$ & Gentle handling & $\begin{array}{l}\text { 1-9 h SD - beginning at } \\
\text { lights-on }\end{array}$ & WKY rats; $\hat{0}$ & Adult (300 g) & Immediately after SD & DD, RPA & $\begin{array}{l}\text { Right CTX, Right } \\
\text { HIPP }\end{array}$ \\
\hline $\begin{array}{l}\text { Cirelli C. and Tononi G., } 2000 . \\
\text { (Cirelli and Tononi 2000b) }\end{array}$ & Gentle handling & $\begin{array}{l}8 \mathrm{~h} \text { SD; spontaneously asleep } \\
\text { (S); spontaneously awake (W) }\end{array}$ & WKY rats; $\partial^{\lambda}$ & Adult (300-350 g) & $\begin{array}{l}\text { Immediately after SD; end } \\
\text { of light period for S; end } \\
\text { of dark period for W }\end{array}$ & DD, RPA & CTX \\
\hline $\begin{array}{l}\text { Taishi P. et al., 2001. } \\
\text { (Taishi et al. 2001) }\end{array}$ & Gentle handling & 8 h SD; 2 h RS after 8 h SD & $\begin{array}{l}\text { Spague-Dawley } \\
\text { rats; } \hat{\jmath}\end{array}$ & Adult (320-350 g) & Immediately after SD or RS & RT-PCR, QPCR & CTX, HIPP \\
\hline $\begin{array}{l}\text { Terao A., et al., 2006. } \\
\text { (Terao et al. 2006) }\end{array}$ & Gentle handling & $\begin{array}{l}6 \mathrm{~h} \mathrm{SD} ; 2 \mathrm{~h} \mathrm{RS} \text { after } 6 \mathrm{~h} \mathrm{SD}- \\
\text { beginning at light onset }\end{array}$ & Wistar rats $\hat{\sigma}^{\lambda}$ & 2-3 months & Immediately after SD or RS & MA & CTX, BF, HYPO \\
\hline $\begin{array}{l}\text { Cirelle C. and Tononi G., } 2004 . \\
\text { (Cirelli and Tononi 2004) }\end{array}$ & $\begin{array}{l}\text { Gentle handling for } \\
\text { short-term SD; DOW } \\
\text { for long-term SD }\end{array}$ & $\begin{array}{l}8 \mathrm{~h} \mathrm{SD}(\mathrm{s}-\mathrm{SD}) ; 7 \mathrm{~d}(\mathrm{I}-\mathrm{SD})- \\
\text { beginning at lights-on }\end{array}$ & WKY rats; $\hat{\sigma}^{2}$ & Adult (300-450 g) & Immediately after SD & RPA, QPCR & $\begin{array}{l}\text { Right CTX (also } \\
\text { liver and muscle) }\end{array}$ \\
\hline $\begin{array}{l}\text { Cirelle C. and Tononi G., } 1998 . \\
\text { (Cirelli and Tononi 1998) }\end{array}$ & Gentle handling & $\begin{array}{l}3 \mathrm{~h} \text { SD; } 3 \text { h spontaneously asleep } \\
\text { (S); } 3 \text { h spontaneously awake (W) }\end{array}$ & WKY rats; $\partial^{\lambda}$ & Adult (300-350 g) & $\begin{array}{l}\text { Immediately after SD; } \\
\text { During dark phase for W rats }\end{array}$ & DD, RPA & Left CTX \\
\hline $\begin{array}{l}\text { Mackiewicz M., et al., } 2003 . \\
\text { (Mackiewicz et al. 2003) }\end{array}$ & Gentle handing & $\begin{array}{l}12 \mathrm{~h} \mathrm{SD} \text { beginning at } \\
\text { lights-on }(7 \mathrm{am})\end{array}$ & Fischer rats $\hat{0}$ & $\begin{array}{l}2 \text { months } \\
(180-200 \mathrm{~g})\end{array}$ & $\begin{array}{l}\text { Multiple time points } \\
\text { throughout day - all } \\
\text { with time-matched controls }\end{array}$ & WB & $\begin{array}{l}\text { CTX, LC, DRN, } \\
\text { TMN, VDB, HDB, } \\
\text { VLPO }\end{array}$ \\
\hline
\end{tabular}


of sleep by the gentle-handling method indicate they are kept awake $~ 94 \%$ of the deprivation period (Leenaars et al. 2011). Thus, the technique used to produce a protracted awake state needs to be carefully considered in evaluating the impact of sleep deprivation on various outcomes. It is certain that the choice of a sleep deprivation method ultimately influences the classes of genes responsible for specific cellular functions (e.g., plasticity, etc.) due to the differences in activity, stress, etc. associated with a given deprivation technique. Investigators in choosing a deprivation procedure must balance the benefit(s) of the technique (i.e. increased animal processing for automated techniques) with the cost (e.g., an increased stress response) of its use.

\section{Established hypotheses}

The regulation of the sleep-wake cycle has been one of the central questions of sleep research. The presence of sleep or sleep-like states across phyla suggests that sleep is a behavior essential to survival. Additionally, sleep deprivation can cause death sooner than food deprivation in both rats (Rechtschaffen et al. 1983) and Drosophila (Shaw et al. 2002), further supporting sleep's necessity. As such, sleep must be regulated and maintained. Unfortunately, the precise mechanisms underlying sleep behavior are still not fully elucidated.

The most established and accepted model explaining the alteration between sleep and wake is the two-process model of sleep regulation (Borbely 1982; Borbely and Achermann 1999). Presented in the early 1980's, this model posits that two distinct processes control the alteration: the circadian clock and the sleep homeostat. Circadian mechanisms, termed Process $\mathrm{C}$, involve sustained rhythmic oscillations for sleep propensity across a 24 hour period. Process $\mathrm{C}$ is based in the suprachiasmatic nucleus $(\mathrm{SCN})$ and has been well characterized. Circadian clock genes are the main modulators of Process $\mathrm{C}$ and regulate sleep tendency to occur at ecologically appropriate times. Additionally, clock genes have been shown to modulate other behaviors, such as feeding, seeming to play a role in regulating basic survival behaviors (McGlincy et al. 2012). Interestingly, sleep deprivation and limited sleep influences the expression of the clock genes themselves (Wisor et al. 2002; Franken et al. 2006; Moller-Levet et al. 2013).

The homeostatic mechanisms, termed process S, regulate sleep propensity across the sleep-wake cycle, in that the drive to sleep increases as wakefulness continues. Accordingly, sleep propensity decreases at sleep onset. Studies using EEG have shown an increase in delta power after longer periods of wakefulness, providing support for the regulatory role of Process S (Dijk and Beersma 1989; Franken et al. 2001; Dijk and Lockley 2002) in the sleepwake cycle. One important distinction between these two processes is that the sleep-wake ratio drives Process $\mathrm{S}$ mechanisms, whereas Process $C$ is self-sustaining, independent of the sleep-wake ratio. It should be noted that chronic sleep restriction initially instigates enhanced sleep and slow wave activity during the opportunity for sleep but these effects of sleep restriction habituate rapidly (Kim et al. 2013).

Process $\mathrm{S}$ is also called the sleep homeostat because it regulates the level of sleep propensity. The mechanisms involved in Process S are less characterized but suggest a restorative and/or repairing function of sleep. Thus, the two-process model of sleep regulation suggests that Process $\mathrm{S}$ is responsible for the function of sleep and Process $\mathrm{C}$ is responsible for influencing the timing of sleep. A number of hypotheses on the function of sleep have been proposed based on this model of dualistic control.

\section{Energy hypothesis}

The function of sleep, according to Benington and Heller's energy hypothesis, is to restore the brain energy stores that are depleted during wakefulness (Benington and Heller 1995). Wakefulness is associated with increased neuronal activity and consequently, increased energy demands. These demands are thought to result in depletion of energy stores during wakefulness. One important energy source for neuronal activity is ATP, which is required for neuronal depolarization. ATP is produced in the inner mitochondrial membrane by the oxidative phosphorylation system (OXPHOS). Mitochondrial (Nadh2 and Cox1) and nuclear (Cox4 and Atp5a) genes encoding proteins involved in OXPHOS, such as Nadh2, are upregulated after only 3 hours of sleep deprivation (Cirelli and Tononi 1999a; Terao et al. 2003a; Nikonova et al. 2010) (Table 2, Additional file 1: Table S1). These observations support the theory that wakefulness increases the demand for energy.

Accordingly, energy store depletion should induce sleep. Therefore, it is believed that the increased demand for ATP is initially produced by increasing the activity of OXPHOS. However, as wakefulness continues, ATP stores become depleted and sleep is initiated. Increased ATP expenditure would produce increased levels of adenosine, which has been shown to promote sleep (Porkka-Heiskanen et al. 1997). Furthermore, extracellular levels of adenosine in the cerebral cortex have been shown to increase with sustained wakefulness. Accordingly, adenosine may act as modulator of the sleep-wake cycle and promote sleep when energy levels become depleted. Interestingly, extracellular ATP is believed to also play a role in initiating sleep. Extracellular ATP binds to type 2 purine receptors causing glia to release cytokines (e.g., IL1, TNF) which also act through adenosine to promote sleep (Clinton et al. 2011; Frank 2012).

\section{Synaptic homeostasis hypothesis}

Sleep appears to promote brain plasticity including memory enhancement and stabilization. Although the mechanism 
for this property of sleep is unknown there are a number of hypotheses for this including the synaptic homeostasis hypothesis or SHY. SHY proposes that sleep regulates synaptic weight and makes the following 4 predictions: 1) synaptic potentiation in several cortical structures is associated with wakefulness; 2) synaptic potentiation has been tied to the regulation of slow-wave sleep; 3) synaptic downscaling is associated with slowwave activity; 4) synaptic downscaling is tied to the beneficial effects of sleep on neural connections as evidenced by performance (Tononi and Cirelli 2003).

During wakefulness, genes encoding proteins involved in synaptic plasticity, specifically long-term potentiation (LTP), are upregulated during wakefulness and down regulated during sleep. The plasticity-related genes $A r c$, brain-derived neurotropic factor (BDNF), Homerla, and nerve growth factor-induced gene A (NGFI-A; also known as Egrl) are among the best documented plasticity-related genes to be state-dependent. Specifically, these genes have increased expression during wakefulness and sleep deprivation (Cirelli and Tononi 2000b, a; Cirelli et al. 2004). Moreover, a positive correlation was shown in rats between $B D N F$ expression and exploratory behavior, even when duration of wakefulness was controlled (Huber et al. 2007). Consequently, synaptic potentiation of cortical networks occurs during wakefulness through BDNF, resulting in a net increase of synaptic strength (Tononi and Cirelli 2003). Although considered state-regulated, Arc, Homer 1a, and NGFI-A have not been shown to be associated with exploratory behavior.

Additionally, BDNF expression increase was associated with increased slow-wave activity (SWA) during subsequent sleep (Huber et al. 2007). According to this hypothesis, synaptic potentiation is also linked to SWA in that synaptic downscaling occurs during this time. Downscaling refers to a proportional reduction in the strength of all synapses onto the same neuron. Therefore, downscaling results in a decrease in synaptic weight without interfering with the relative differences in synaptic strength important for memory traces. Taken together, BDNF counteracts the increase of synaptic strength during waking with a subsequent increase of SWA during sleep, resulting in synaptic downscaling. In this way, BDNF is thought to be a possible modulator of the homeostatic sleep response at the molecular level.

Downscaling of synaptic strength would benefit neuronal function by limiting energy expenditure. Metabolic demands due to neuronal repolarizations following postsynaptic potentials account for approximately $44 \%$ of the energy required for the cerebral cortex (Howarth et al. 2012). Increased synaptic strength also increases energy need. Therefore, synaptic downscaling that occurs during sleep maintains energy efficiency of the cerebral cortex. However, there are some concerns about SHY despite experimental evidence supporting this elegant hypothesis. See Frank (Frank 2012) for a comprehensive review of the strengths and weaknesses of the SHY hypothesis.

\section{Macromolecular biosynthesis hypothesis}

In 2007, a microarray study found that the most abundant group of genes upregulated in the cortex and hypothalamus of mice during sleep encoded proteins involved in macromolecule biosynthesis (Mackiewicz et al. 2007). For example, heme biosynthesis in the cortex is one pathway upregulated during sleep. Some of the genes upregulated in this pathway encode enzymes of the heme biosynthesis pathway, proteins that regulate heme level, and heme containing proteins. Structural components of ribosomes, translation initiating factors, and transcripts involved in tRNA activation are among the subcategories of upregulated genes involved in protein synthesis (Mackiewicz et al. 2007). Another biosynthetic pathway upregulated during sleep is protein synthesis. Therefore, sleep seems likely to be the primary state for synthesis of proteins and other macromolecules.

Furthermore, genes encoding enzymes of the cholesterolsynthesis pathway increase progressively during sleep. Specifically, these upregulated genes encode proteins involved in cholesterol uptake and transport, as well as chaperones and transcription factors responsible for regulating transcription of cholesterol-related genes (Mackiewicz et al. 2007). The increase in cholesterol biosynthesis is likely to increase the amount of membrane cholesterol. Cholesterol is a component of the cell membrane and modulates the membrane's fluidity over the range of physiological temperatures. Furthermore, cholesterol aids in signal transduction through its structural role in membrane microdomians called lipid rafts. Additionally, transcript levels for genes encoding proteins involved in lipid rafts, such as flotilin, are also upregulated during sleep. Lipid rafts modulates signal strength by corralling neurotransmitter receptors with other signaling molecules, increasing the likelihood that they interact (Simons and Toomre 2000). Taken together, sleep is important for membrane stability and signal transduction. These observations suggest that the function of sleep is to repair and replenish in preparation for the upcoming demands of wakefulness.

\section{Molecular consequences of prolonged sleep deprivation}

Acute sleep deprivation up to 6 hours results in gene expression resembling those seen during wakefulness. However, as sleep deprivation is prolonged, gene expression patterns begin to suggest increased cellular stress. Cellular stress can occur when there is an interruption in physiological balances (McEwen 2006), such as those necessary for protein and calcium homeostasis in the ER (Naidoo et al. 2005). Sleep deprivation studies consistently result in increased expression of transcripts associated with stress 
Table 2 Genes shown in the literature to be upregulated in the cortex after sleep deprivation

\begin{tabular}{|c|c|c|c|c|c|c|}
\hline & 3 hours & 6 hours & 8 hours & 12 hours & 24 hours & 7 days total SD \\
\hline $\begin{array}{l}\text { Immediate early } \\
\text { genes/transcription } \\
\text { factors }\end{array}$ & $\begin{array}{l}\text { Arc (Cirelli and Tononi 2000a; } \\
\text { Cirelli 2002) Fosb (Cirelli and } \\
\text { Tononi 1998; Cirelli 2002) Egr1 } \\
\text { (Cirelli and Tononi 1998; Cirelli } \\
\text { 2002) Homer1a (Mackiewicz et al. } \\
\text { 2007; Maret et al. 2007) }\end{array}$ & $\begin{array}{l}\text { Arc (Terao et al. 2006; Thompson et al. } \\
\text { 2010; Maret et al. 2007) Fosb (Maret et al. } \\
\text { 2007; Terao et al. 2003a) Fra-2 (Terao et al. } \\
\text { 2003a; Terao et al. 2006; Maret et al. 2007) } \\
\text { Junb (Terao et al. 2003a) Egrr (Terao et al. } \\
\text { 2003a; Terao et al. 2006) Egr2 (Maret et al. } \\
\text { 2007) Egr3 (Terao et al. 2003a; Terao et al. } \\
\text { 2006; Maret et al. 2007) Homeria (Maret } \\
\text { et al. 2007; Mackiewicz et al. 2007) }\end{array}$ & $\begin{array}{l}\text { Arc (Taishi et al. 2001; Cirelli 2002; Cirelli } \\
\text { and Tononi 2000a, b; Cirelli et al. 2006) } \\
\text { Fosb (Cirelli et al. 2006) Fra (Cirelli et al. } \\
\text { 2006) CHOP (Cirelli and Tononi 2000b; } \\
\text { Cirelli 2002; Cirelli et al. 2004) IER5 (Cirelli } \\
\text { and Tononi 2000b; Cirelli 2002) Egr1 } \\
\text { (Cirelli and Tononi 2000b; Cirelli 2002; } \\
\text { Cirelli et al. 2006) Ngf1-b (Cirelli and } \\
\text { Tononi 2000b; Cirelli 2002; Cirelli et al. } \\
\text { 2006) Egr2 (Cirelli et al. 2006) N-ras (Cirelli } \\
\text { 2002; Cirelli and Tononi 2000b) Stat3 } \\
\text { (Cirelli and Tononi 2000b; Cirelli 2002) } \\
\text { Homerla (Cirelli et al. 2006) }\end{array}$ & $\begin{array}{l}\text { Homerla } \\
\text { (Mackiewicz et al. } \\
\text { 2007) }\end{array}$ & $\begin{array}{l}\text { Egr2 (Conti et al. } \\
\text { 2007) Homer1a } \\
\text { (Conti et al. 2007) }\end{array}$ & $\begin{array}{l}\text { Arc (Cirelli et al. 2006) Fosb (Cirelli } \\
\text { et al. 2006) Fra (Cirelli et al. 2006) } \\
\text { Egr1 (Cirelli et al. 2006) Ngf1-b } \\
\text { (Cirelli et al. 2006) Egr2 (Cirelli } \\
\text { et al. 2006) Homerla (Cirelli et al. } \\
\text { 2006) Ania-1 (Cirelli et al. 2006) }\end{array}$ \\
\hline $\begin{array}{l}\text { Energy metabolism/ } \\
\text { energy balance }\end{array}$ & $\begin{array}{l}\text { Cox1 (Cirelli 2002; Cirelli and } \\
\text { Tononi 1998, 1999a, b, 2000b; } \\
\text { Cirelli et al. 2004; Cirelli and } \\
\text { Tononi 2004; Naidoo et al. 2005) } \\
\text { Cox4 (Cirelli et al. 2004; Nikonova } \\
\text { et al. 2010) Atp5a (Cirelli et al. } \\
\text { 2004; Cirelli and Tononi 2004) } \\
\text { Nadh2 (Cirelli 2002; Cirelli and } \\
\text { Tononi 1998, 1999a, b) }\end{array}$ & Nrf-1 (Nikonova et al. 2010) & $\begin{array}{l}\text { Glut1 (Cirelli 2002; Cirelli and Tononi } \\
\text { 2000b) Vgf (Cirelli 2002; Cirelli and } \\
\text { Tononi 2000b; Cirelli et al. 2006) Ucp2 } \\
\text { (Cirelli et al. 2004; Cirelli and Tononi } \\
\text { 2004) }\end{array}$ & $\begin{array}{l}\text { Cox1 (Nikonova } \\
\text { et al. 2010) Cox4 } \\
\text { (Nikonova et al. } \\
\text { 2010) Atp5a } \\
\text { (Nikonova et al. } \\
\text { 2010) Ucp2 } \\
\text { (Nikonova et al. } \\
\text { 2010) }\end{array}$ & & Vgf (Cirelli et al. 2006) \\
\hline $\begin{array}{l}\text { Chaperones/heat } \\
\text { shock proteins/ } \\
\text { stress response }\end{array}$ & & $\begin{array}{l}\text { BiP (Maret et al. 2007; Terao et al. 2006; } \\
\text { Mackiewicz et al. 2007; Naidoo et al. 2005) } \\
\text { Erp72 (Terao et al. 2006) Grp94 (Maret } \\
\text { et al. 2007; Terao et al. 2006) Hsp90ab1 } \\
\text { (Maret et al. 2007) Hspb1 (Maret et al. } \\
\text { 2007) Gadd45a (Mackiewicz et al. 2007) } \\
\text { Gadd45b (Maret et al. 2007) Calr } \\
\text { (Mackiewicz et al. 2007; Maret et al. 2007) } \\
\text { Dnajc3 (Mackiewicz et al. 2007) Dnajb5 } \\
\text { (Mackiewicz et al. 2007) Dnajb11 } \\
\text { (Mackiewicz et al. 2007) Dnajc1 } \\
\text { (Mackiewicz et al. 2007) Hsp105 } \\
\text { (Mackiewicz et al. 2007) Hspala } \\
\text { (Mackiewicz et al. 2007) Hspalb } \\
\text { (Mackiewicz et al. 2007) Nrf2 (Nikonova } \\
\text { et al. 2010) }\end{array}$ & $\begin{array}{l}\text { BiP (Cirelli and Tononi 2000b; Cirelli } \\
\text { 2002; Cirelli et al. 2004; Naidoo et al. } \\
\text { 2005) PERK (Cirelli et al. 2004) Erp72 } \\
\text { (Cirelli and Tononi 2000b; Cirelli 2002) } \\
\text { Hspa9 (Cirelli and Tononi 2000b; Cirelli } \\
\text { 2002) Grp94 (Cirelli and Tononi 2000b) } \\
\text { Hsp60 (Cirelli and Tononi 2000b; Cirelli } \\
\text { 2002) Hsp70 (Cirelli and Tononi 2000b; } \\
\text { Cirelli 2002) Calr (Cirelli et al. 2006) Ppp3 } \\
\text { (Cirelli et al. 2004) }\end{array}$ & $\begin{array}{l}\text { BiP (Naidoo et al. } \\
\text { 2005; Mackiewicz } \\
\text { et al. 2007) }\end{array}$ & $\begin{array}{l}\text { Hspb1 (Conti } \\
\text { et al. 2007) }\end{array}$ & $\begin{array}{l}\text { BiP (Cirelli et al. 2006) Mrp14 } \\
\text { (Cirelli et al. 2006) Taf9b (Cirelli } \\
\text { et al. 2006) Cort (Cirelli et al. } \\
\text { 2006) Hspb1 (Cirelli et al. 2006) } \\
\text { Hspa 1a (Cirelli et al. 2006) Cryab } \\
\text { (Cirelli et al. 2006) Gllg15b (Cirelli } \\
\text { et al. 2006) Mgst1 (Cirelli et al. } \\
\text { 2006) Gpx3 (Cirelli et al. 2006) } \\
\text { CYP4F4 (Cirelli et al. 2006) }\end{array}$ \\
\hline $\begin{array}{l}\text { DNA binding/ } \\
\text { regulation of } \\
\text { transcription }\end{array}$ & & Dbp (Maret et al. 2007) & & & & $\begin{array}{l}\text { Dbp (Cirelli et al. 2006) Atff5 } \\
\text { (Cirelli et al. 2006) Neurod7 (Cirelli } \\
\text { et al. 2006) c-myc (Cirelli et al. } \\
\text { 2006) }\end{array}$ \\
\hline $\begin{array}{l}\text { Vesicle- and } \\
\text { synapse-related }\end{array}$ & & & $\begin{array}{l}\text { Scg2 (Cirelli and Tononi 2000b; Cirelli } \\
\text { 2002) Syt4 (Cirelli 2002; Cirelli and } \\
\text { Tononi 2000b) }\end{array}$ & & & $\begin{array}{l}\text { Scg2 (Cirelli et al. 2006) VAP1 } \\
\text { (Cirelli et al. 2006) }\end{array}$ \\
\hline $\begin{array}{l}\text { Growth factors/ } \\
\text { adhesion molecules }\end{array}$ & & $\begin{array}{l}\text { Bdnf (Maret et al. 2007) Vegfa (Maret } \\
\text { et al. 2007) }\end{array}$ & $\begin{array}{l}\text { Bdnf (Cirelli 2002; Taishi et al. 2001; Cirelli } \\
\text { and Tononi 2000a, b; Cirelli et al. 2006) } \\
\text { TrkB (Cirelli and Tononi 2000a; Cirelli } \\
\text { 2002; Cirelli and Tononi 2000b) Cntn1 } \\
\text { (Cirelli and Tononi 2000b; Cirelli 2002) }\end{array}$ & & $\begin{array}{l}\text { Bdnf (Conti et al. } \\
\text { 2007) Ifrd1 (Conti } \\
\text { et al. 2007) }\end{array}$ & $\begin{array}{l}\text { Bdnf (Cirelli et al. 2006) Ntm } \\
\text { (Cirelli et al. 2006) Gas (Cirelli } \\
\text { et al. 2006) }\end{array}$ \\
\hline
\end{tabular}

Cononi 2004: Naidoo et al. 2005)

Cox4 (Cirelli et al. 2004; Nikonova

(c)

Nadh2 (Cirelli 2002; Cirelli and

Chaperones/heat

shock proteins/

Bip (Maret et al. 2007; Terao et al. 2006; (Eplewicz et al. 2007, Naidoo et al. 2005 tal. 2007: Terao 2 al. 2006) Hsp900ar (Mackiewicz et al. 2007) Dnajbil

(Mackiewicz et al 2007) Nrf2 (Nikonova

tal. 2010$)$

scg2 (Cirelli and Tononi 2000b; Cirell 2002) Syt4 (Cichis

(Cirelli and Tononi 2000b; Cirelli 2002) 
Table 2 Genes shown in the literature to be upregulated in the cortex after sleep deprivation (Continued)

Receptors

Adrala (Cirelli 2002; Cirelli and Tononi

2000b) Adrb2 (Cirelli 2002; Cirelli and

Tononi 2000b) Gabrb3 (Cirelli 2002

Cirelli and Tononi 2000b) Grin2a (Cirelli

2002; Cirelli and Tononi 2000b) Glur2

Glur3 (Girelli and Tononi 2000 ; Girell

2002) Chrnb2 (Cirelli 2002; Cirlliend

2002) Chmo2 (Cirli 2002, Clielli and

Tononi $2000 \mathrm{~b}$ Thit (Cirelli and Tononi

2000b; Cirelli 2002) Itpr3 (Cirelli et al.

Enzymes

Sgk1 (Maret et al. 2007)

Hormone/ Hormone

regulation

Other

Cdkn1a (Maret et al. 2007) Dusp14

(Maret et al. 2007) Dusp4 (Maret et al.

2007) Nptx2 (Maret et al. 2007) Pdia3

(Maret et al. 2007) Vip (Maret et al.

2007) Xbp-1 (Maret et al. 2007)
tPA (Taishi et al. 2001) CaM (Cirelli

2002; Cirelli and Tononi 2000b) Ccnd2 (Cirelli and Tononi 2000b; Cirelli 2002) Lmo-4 (Cirelli and Tononi 2000b; Cirell 2002) Mt3 (Cirelli and Tononi 2000b; Cirelli 2002) Junb (Cirelli et al. 2006)

Cebpb (Cirelli et al. 2006)
Ntsr (Cirelli et al. 2006)

Aloxi2 (Cirelli et al. 2006) Sgki
Sultral (Conti Sultral (Cirelli et al. 2006)

(Conti et al. 2007) (Cirelli et al. 2006) Fdft1 (Cirell

$\begin{array}{lll}\text { Tononi 2000b; Cirelli 2002) Gpd1 } & \text { Ret (Conti et al. } & \text { et al. 2006) Ptgs2 (Cirelli et al. } \\ \text { (Cirelli et al. 2006) Fkbpb1a (Cirelli et al. } & \text { 2007) Gpd1 } & \text { 2006) Pdk2 (Cirelli et al. 2006) } \\ \text { 2004) } & \text { (Conti et al. 2007) } & \text { Gpd1 (Cirelli et al. 2006) Nao1 }\end{array}$

$\begin{array}{lll}\text { Tononi 2000b; Cirelli 2002) Gpd1 } & \text { Ret (Conti et al. } & \text { et al. 2006) Ptgs2 (Cirelli et al. } \\ \text { (Cirelli et al. 2006) Fkbpbla (Cirelli et al. } & \text { 2007) Gpd1 } & \text { 2006) Pdk2 (Cirelli et al. 2006) } \\ \text { 2004) } & \text { (Conti et al. 2007) } & \text { Gpdl (Cirelli et al. 2006) Naol }\end{array}$

(Cirelli et al. 2006) Aldoc (Cirell

et al. 2006) Glo (Cirelli et a

Crhbp (Conti

et al. 2007)

Crhbp (Cirelli et al. 2006) Crh

(Cirelli

et al. 2006)

Gfap (Conti et al. TPA (Cirelli et al. 2006) IgK

2007) Anp32a (Cirelli et al. 2006) Junb (Cirelli

(Conti et al. 2007) et al. 2006) Hbal (Cirelli et al.

Mtra (Conti et al 2006) Cebpb (Cirelli et al. 2006)

2007)

Rp/21(Cirelli et al. 2006) Alb

(Cirelli et al. 2006) Npy (Cirelli

et al. 2006) Hbb (Cirelli et al.

Syt12 (Cirelli

Syt 12 (Cirelli et al. 2006) Vip

et al. 2006) Grifin (Cilli

2006) Ccnd3 (Cir (Ciriti et al.

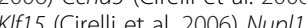

(Girelli alli et al. 2006) Nup/

et al. 2006) Ptp4a2 (Cirelli et

et al. 2006) Ptp4a2 (Cirelli et al.
2006) Ctnnbi (Cirelli et al. 2006)

Note: This is a compilation from multiple research articles and does not give a complete account of how a particular gene's expression changes across durations of deprivation. The absence of genes in the 12 and 24 hour columns comes from a gap in the research for those durations and does not imply a decrease in the number of genes upregulated after 12 and 24 hours of sleep deprivation. 
response in the ER (ie, sleep deprivation can be considered a cellular stressor). The ER is an organelle that regulates protein folding and transport through various pathways and post-translational modifications. Molecular chaperone proteins, such as binding immunoglobulin protein (BiP; also known as GRP78 and HSPA5) and glucose-related protein, $94 \mathrm{kDa}$ (GRP94; also known as HSP90B1), aid in protein folding by stabilizing protein intermediates. Protein misfolding can occur when there is a disturbance in ER homeostasis, causing cellular stress. Accumulation of misfolded or unfolded proteins triggers the UPR.

The UPR is an adaptive mechanism in the ER to control and limit the amount of unfolded proteins that could become toxic and reinstate protein homeostasis. Three main mechanisms make up the UPR. The first involves increasing transcription of chaperone proteins to aid in the proper folding of proteins. Second, protein translation is attenuated by activating the serine-threonine kinase PKR-like ER kinase (PERK), which then phosphorylates the eukaryotic initiation factor $2 \alpha$ (eIF2 $\alpha)$. Finally, unfolded proteins are removed from the ER for degradation. If stress is prolonged, these mechanisms cannot restore homeostasis. Apoptotic pathways are initiated by the activation of CHOP (C/EBP homologous protein), JNK (c-jun NH2 terminal kinase), and caspases such as Caspase 9 and ensure elimination of the aberrant proteins.

Sleep deprivation studies consistently show upregulation of genes involved in the UPR (Table 2). Transcript levels of BiP, a key marker of UPR activation, is upregulated in the cerebral cortex after only 6 hours of sleep deprivation in both mice (Naidoo et al. 2005; Mackiewicz et al. 2007) and rats (Cirelli et al. 2004) and continues to stay upregulated after 7 days of total sleep deprivation (Cirelli et al. 2006). Further, PERK expression has also been shown to be upregulated after a short duration of sleep deprivation (Cirelli et al. 2004). However, although the PERK pathway is activated after 6 hours (Naidoo et al. 2005), expression of PERK mRNA increases with 8 hours of sleep deprivation (Table 2). Taken together, these findings lend credence to the theory that sleep is associated with protein translation, with likely attenuation of this during sleep deprivation. Thus, an alteration in protein translation may be a key consequence of sleep deprivation.

\section{Conclusion}

The majority of the studies reviewed were microarray studies which have distinct limitations. Microarrays do not contain all genes in a given genome allowing for the possibility of missing critical genes. Although the newer technologies for transcriptomic analyses (e.g., NextGen) contain the entire genome, both microarrays and NextGen produce large datasets which require bioinformatics approaches to identify relevant pathways. This is illustrated in the paper by Wang (Wang et al. 2010) on sleep deprivation where a variety of data analysis strategies were used to identify pathways impacted by sleep disruption (e.g., synaptogenesis, etc.). While gene expression changes can be identified it is difficult to determine how specific brain cells are impacted by sleep disruption as the tissue evaluated contains a variety of cell types (e.g., neurons, glia, etc.). New approaches such as bacTRAP are beginning to solve these problems (Doyle et al. 2008; Emery and Barres 2008; Heiman et al. 2008).

Sleep research in animals utilizing microarrays and other transcriptomic approaches has begun to yield a better understanding of the influence of the sleep-wake cycle on the brain. Specifically, studies utilizing these modern molecular techniques have shown that the homeostasis or balance between the two states is important for normal brain functioning. When this cycle is disrupted, cellular stress pathways respond to reduce the negative consequences. However, protracted activation of these stress pathways can lead to elimination of these "stressed" cells by apoptosis. Further, the existing studies have efficiently documented the consequences for brain of both short-term and long-term sleep deprivation. However, the existing studies do not allow us to understand the consequences of repeated short-term sleep deprivation - a scenario with more translational impact because it is relevant for the sleep disruption conditions humans are more likely to experience. Although brain is an organ not easily accessed in living humans for transcriptomic or proteomic evaluation there is great interest in examining the blood transcriptome as an accessible window to other organs, including the brain (Moller-Levet et al. 2013; Clinton et al. 2011; Liew et al. 2006; Kohane and Valtchinov 2012). What are the consequences of a repeated activation of these stress pathways? Do they begin activating apoptosis earlier? Or are regular patterns of shorter sleep durations having no specific influence on health? Sleep studies need to begin expanding the limits of sleep deprivation to include more relevant human patterns of sleep limitations and disruptions. Only then can we start locating particular pathways where intervention is possible to modulate the negative effects of chronic sleep deficiency.

\section{Additional file}

Additional file 1: Table S1. List of gene symbol, full gene name, and aliases of all genes listed in Table 2 .

\section{Abbreviations}

Experimental methods

DD: Differential display; ISH: In situ hybridization; MA: Microarray; QPCR: Quantitative PCR; RPA: Rnase protection assay; RT-PCR: Reverse-transcriptase PCR; WB: Western blot

Brain regions

AMY: Amygdala; BF: Basal forebrain; CB: Cerebellum; CTX: Cortex; DRN: Dorsal raphe nucleus; ENT: Entorhinal cortex; FCTX: Frontal cortex; HCRT: Hypocretin neurons; HDB: Horizontal limb of the diagonal band of Broca; 
HIPP: Hippocampus; HYPO: Hypothalamus; LC: Locus coeruleus; MD: Medulla; ORB: Orbital cortex; P: Pons; PFC: Prefrontal cortex; PMCo: Posteromedial cortical amygdala; SCN: Suprachiasmatic nucleus; TH: Thalamus; TMN: Tuberomammillary nucleus; VDB: Verticallimb of the diagonal band of Broca; VLPO: Ventrolateral preoptic area.

\section{Competing interests}

The authors declare that they have no competing interest.

\section{Authors' contributions}

AE and DM analyzed and reviewed all the studies included in the paper and were significantly involved in the drafting and editing of the paper. $\mathrm{JH}, \mathrm{JO}$, and $\mathrm{CR}$ provided intellectual ideas included in the paper. All authors have given final approval of the paper and acknowledge their accountability of the contents of the paper.

\section{Author details}

${ }^{1}$ School of Medicine, West Virginia University, Morgantown, WW, USA. ${ }^{2}$ School of Pharmacy, West Virginia University, Morgantown, WV, USA. ${ }^{3}$ Toxicology and Molecular Biology Branch, CDC-NIOSH, 1095 Willowdale Rd., Morgantown, WV 26505, USA.

Received: 26 June 2014 Accepted: 25 November 2014

Published: 11 December 2014

\section{References}

Allada R, Siegel JM (2008) Unearthing the phylogenetic roots of sleep. Curr Biol 18(15):R670-R679, doi:10.1016/j.cub.2008.06.033

Ayas NT, White DP, Manson JE, Stampfer MJ, Speizer FE, Malhotra A, Hu FB (2003) A prospective study of sleep duration and coronary heart disease in women. Arch Intern Med 163(2):205-209

Barf RP, Desprez T, Meerlo P, Scheurink AJ (2012) Increased food intake and changes in metabolic hormones in response to chronic sleep restriction alternated with short periods of sleep allowance. Am J Physiol Regul Integr Comp Physiol 302(1):R112-R117, doi:10.1152/ajpregu.00326.2011

Basheer R, Halldner L, Alanko L, McCarley RW, Fredholm BB, Porkka-Heiskanen T (2001) Opposite changes in adenosine A1 and A2A receptor mRNA in the rat following sleep deprivation. Neuroreport 12(8):1577-1580

Benington JH, Heller HC (1995) Restoration of Brain Energy-Metabolism as the Function of Sleep. Prog Neurobiol 45(4):347-360

Borbely AA (1982) A two process model of sleep regulation. Hum Neurobiol 1(3):195-204

Borbely AA, Achermann P (1999) Sleep homeostasis and models of sleep regulation. J Biol Rhythm 14(6):557-568

Brown MK, Naidoo N (2010) The UPR and the anti-oxidant response: relevance to sleep and sleep loss. Mol Neurobiol 42(2):103-113, doi:10.1007/ s12035-010-8114-8

Cappuccio FP, Taggart FM, Kandala NB, Currie A, Peile E, Stranges S, Miller MA (2008) Meta-analysis of short sleep duration and obesity in children and adults. Sleep 31(5):619-626

Chaput JP, Despres JP, Bouchard C, Tremblay A (2007) Association of sleep duration with type 2 diabetes and impaired glucose tolerance. Diabetologia 50(11):2298-2304, doi:10.1007/s00125-007-0786-x

Chen JC, Brunner RL, Ren H, Wassertheil-Smoller S, Larson JC, Levine DW, Allison M, Naughton MJ, Stefanick ML (2008) Sleep Duration and Risk of Ischemic Stroke in Postmenopausal Women. Stroke 39(12):3185-3192, doi:10.1161/ Strokeaha.108.521773

Cirelli C (2002) Invited review: How sleep deprivation affects gene expression in the brain: a review of recent findings. J Appl Physiol 92(1):394-400

Cirelli C, Tononi G (1998) Differences in gene expression between sleep and waking as revealed by mRNA differential display. Mol Brain Res 56(1-2):293-305

Cirelli C, Tononi G (1999a) Differences in brain gene expression between sleep and waking as revealed by mRNA differential display and CDNA microarray technology. J Sleep Res 8:44-52

Cirelli C, Tononi G (1999b) Differences in gene expression during sleep and wakefulness. Ann Med 31(2):117-124

Cirelli C, Tononi G (2000a) Differential expression of plasticity-related genes in waking and sleep and their regulation by the noradrenergic system. J Neurosci 20(24):9187-9194
Cirelli C, Tononi G (2000b) Gene expression in the brain across the sleep-waking cycle. Brain Res 885(2):303-321

Cirelli C, Tononi G (2004) Uncoupling proteins and sleep deprivation. Arch Ital Biol 142(4):541-549

Cirelli C, Gutierrez CM, Tononi G (2004) Extensive and divergent effects of sleep and wakefulness on brain gene expression. Neuron 41(1):35-43

Cirelli C, Faraguna U, Tononi G (2006) Changes in brain gene expression after long-term sleep deprivation. J Neurochem 98(5):1632-1645, doi:10.1111/ j.1471-4159.2006.04058.x

Clinton JM, Davis CJ, Zielinski MR, Jewett KA, Krueger JM (2011) Biochemical regulation of sleep and sleep biomarkers. J Clin Sleep Med 7(5 Suppl):S38-S42, doi:10.5664/JCSM.1360

Coenen AM, van Luijtelaar EL (1985) Stress induced by three procedures of deprivation of paradoxical sleep. Physiol Behav 35(4):501-504

Conti B, Maier R, Barr AM, Morale MC, Lu X, Sanna PP, Bilbe G, Hoyer D, Bartfai T (2007) Region-specific transcriptional changes following the three antidepressant treatments electro convulsive therapy, sleep deprivation and fluoxetine. Mol Psychiatry 12(2):167-189, doi:10.1038/sj.mp.4001897

Das G, Gopalakrishnan A, Faisal M, Mallick BN (2008) Stimulatory role of calcium in rapid eye movement sleep deprivation-induced noradrenaline-mediated increase in Na-K-ATPase activity in rat brain. Neuroscience 155(1):76-89, doi:10.1016/j.neuroscience.2008.04.069

Datta A, Jingru Q, Khor TH, Teo MT, Heese K, Sze SK (2011) Quantitative neuroproteomics of an in vivo rodent model of focal cerebral ischemia/ reperfusion injury reveals a temporal regulation of novel pathophysiological molecular markers. J Proteome Res 10(11):5199-5213, doi:10.1021/pr200673y

Dattilo M, Antunes HK, Medeiros A, Monico Neto M, Souza HS, Tufik S, de Mello MT (2011) Sleep and muscle recovery: endocrinological and molecular basis for a new and promising hypothesis. Med Hypotheses 77(2):220-222. doi:10.1016/j.mehy.2011.04.017

Dijk DJ, Beersma DG (1989) Effects of SWS deprivation on subsequent EEG power density and spontaneous sleep duration. Electroencephalogr Clin Neurophysiol 72(4):312-320

Dijk DJ, Lockley SW (2002) Integration of human sleep-wake regulation and circadian rhythmicity. J Appl Physiol 92(2):852-862, doi:10.1152/ japplphysiol.00924.2001

Doyle JP, Dougherty JD, Heiman M, Schmidt EF, Stevens TR, Ma G, Bupp S, Shrestha P, Shah RD, Doughty ML, Gong S, Greengard P, Heintz N (2008) Application of a translational profiling approach for the comparative analysis of CNS cell types. Cell 135(4):749-762, doi:10.1016/j.cell.2008.10.029

Emery B, Barres BA (2008) Unlocking CNS cell type heterogeneity. Cell 135 (4):596-598, doi:10.1016/j.cell.2008.10.031

Everson CA, Szabo A (2011) Repeated exposure to severely limited sleep results in distinctive and persistent physiological imbalances in rats. PLoS One 6(8):e22987, doi:10.1371/journal.pone.0022987

Fenzl T, Romanowski CP, Flachskamm C, Honsberg K, Boll E, Hoehne A, Kimura M (2007) Fully automated sleep deprivation in mice as a tool in sleep research. J Neurosci Methods 166(2):229-235, doi:10.1016/j.jneumeth.2007.07.007

Ferrie JE, Shipley MJ, Cappuccio FP, Brunner E, Miller MA, Kumari M, Marmot MG (2007) A prospective study of change in sleep duration: associations with mortality in the Whitehall II cohort. Sleep 30(12):1659-1666

Franco-Perez J, Ballesteros-Zebadua P, Fernandez-Figueroa EA, Ruiz-Olmedo I, Reyes-Grajeda P, Paz C (2012) Sleep deprivation and sleep recovery modifies connexin36 and connexin43 protein levels in rat brain. Neuroreport 23 (2):103-107, doi:10.1097/WNR.0b013e32834e8fcb

Frank MG (2012) Erasing synapses in sleep: is it time to be SHY? Neural Plast 2012:264378, doi:10.1155/2012/264378

Franken P, Chollet D, Tafti M (2001) The homeostatic regulation of sleep need is under genetic control. J Neurosci 21(8):2610-2621

Franken P, Dudley CA, Estill SJ, Barakat M, Thomason R, O'Hara BF, McKnight SL (2006) NPAS2 as a transcriptional regulator of non-rapid eye movement sleep: genotype and sex interactions. Proc Natl Acad Sci U S A 103(18):7118-7123, doi:10.1073/pnas.0602006103

Friedman L, Bergmann BM, Rechtschaffen A (1979) Effects of sleep deprivation on sleepiness, sleep intensity, and subsequent sleep in the rat. Sleep 1(4):369-391

Gottlieb DJ, Redline S, Nieto FJ, Baldwin CM, Newman AB, Resnick HE, Punjabi NM (2006) Association of usual sleep duration with hypertension: the Sleep Heart Health Study. Sleep 29(8):1009-1014

Heiman M, Schaefer A, Gong S, Peterson JD, Day M, Ramsey KE, Suarez-Farinas M, Schwarz C, Stephan DA, Surmeier DJ, Greengard P, Heintz N (2008) A 
translational profiling approach for the molecular characterization of CNS cell types. Cell 135(4):738-748, doi:10.1016/j.cell.2008.10.028

Hendricks JC, Finn SM, Panckeri KA, Chavkin J, Williams JA, Sehgal A, Pack AI (2000) Rest in Drosophila is a sleep-like state. Neuron 25(1):129-138

Howarth C, Gleeson P, Attwell D (2012) Updated energy budgets for neural computation in the neocortex and cerebellum. J Cereb Blood Flow Metab 32(7):1222-1232, doi:10.1038/jcbfm.2012.35

Huber R, Tononi G, Cirelli C (2007) Exploratory behavior, cortical BDNF expression, and sleep homeostasis. Sleep 30(2):129-139

Ikehara S, Iso H, Date C, Kikuchi S, Watanabe Y, Wada Y, Inaba Y, Tamakoshi A, Group JS (2009) Association of sleep duration with mortality from cardiovascular disease and other causes for Japanese men and women: the JACC study. Sleep 32(3):295-301

Kalinchuk AV, McCarley RW, Porkka-Heiskanen T, Basheer R (2010) Sleep deprivation triggers inducible nitric oxide-dependent nitric oxide production in wake-active basal forebrain neurons. J Neurosci 30(40):13254-13264, doi:10.1523/JNEUROSCI.0014-10.2010

Kilduff TS, Lein ES, de la Iglesia H, Sakurai T, Fu YH, Shaw P (2008) New developments in sleep research: molecular genetics, gene expression, and systems neurobiology. J Neurosci 28(46):11814-11818, doi:10.1523/ JNEUROSCI.3768-08.2008

Kim J, Jo I (2010) Age-Dependent Association Between Sleep Duration and Hypertension in the Adult Korean Population. Am J Hypertens 23(12):1286-1291, doi:10.1038/Ajh.2010.166

Kim Y, Chen L, McCarley RW, Strecker RE (2013) Sleep allostasis in chronic sleep restriction: the role of the norepinephrine system. Brain Res 1531:9-16, doi:10.1016/j.brainres.2013.07.048

Kohane IS, Valtchinov VI (2012) Quantifying the white blood cell transcriptome as an accessible window to the multiorgan transcriptome. Bioinformatics 28(4):538-545, doi:10.1093/bioinformatics/btr713

Kong J, Shepel PN, Holden CP, Mackiewicz M, Pack Al, Geiger JD (2002) Brain glycogen decreases with increased periods of wakefulness: implications for homeostatic drive to sleep. J Neurosci 22(13):5581-5587

Kushida CA (2006) Countermeasures for sleep loss and deprivation. Curr Treat Options Neurol 8(5):361-366

Lamond N, Jay SM, Dorrian J, Ferguson SA, Jones C, Dawson D (2007) The dynamics of neurobehavioural recovery following sleep loss. J Sleep Res 16(1):33-41, doi:10.1111/j.1365-2869.2007.00574.x

Leenaars CH, Dematteis M, Joosten RN, Eggels L, Sandberg H, Schirris M, Feenstra MG, Van Someren EJ (2011) A new automated method for rat sleep deprivation with minimal confounding effects on corticosterone and locomotor activity. J Neurosci Methods 196(1):107-117, doi:10.1016/j. jneumeth.2011.01.014

Liew CC, Ma J, Tang HC, Zheng R, Dempsey AA (2006) The peripheral blood transcriptome dynamically reflects system wide biology: a potential diagnostic tool. J Lab Clin Med 147(3):126-132, doi:10.1016/j.lab.2005.10.005

Luckhaupt SE, Tak S, Calvert GM (2010) The prevalence of short sleep duration by industry and occupation in the National Health Interview Survey. Sleep 33 (2):149-159

Luyster FS, Strollo PJ, Zee PC, Walsh JK, Sleep BDAA (2012) Sleep: A Health Imperative. Sleep 35(6):727-734, doi:10.5665/Sleep.1846

Mackiewicz M, Nikonova EV, Zimmerman JE, Galante RJ, Zhang L, Cater JR, Geiger JD, Pack Al (2003) Enzymes of adenosine metabolism in the brain: diurnal rhythm and the effect of sleep deprivation. J Neurochem 85(2):348-357

Mackiewicz M, Shockley KR, Romer MA, Galante RJ, Zimmerman JE, Naidoo N, Baldwin DA, Jensen ST, Churchill GA, Pack Al (2007) Macromolecule biosynthesis: a key function of sleep. Physiol Genomics 31(3):441-457, doi:10.1152/physiolgenomics.00275.2006

Mackiewicz M, Zimmerman JE, Shockley KR, Churchill GA, Pack AI (2009) What are microarrays teaching us about sleep? Trends Mol Med 15(2):79-87, doi:10.1016/j.molmed.2008.12.002

Mallick BN, Singh A (2011) REM sleep loss increases brain excitability: role of noradrenaline and its mechanism of action. Sleep Med Rev 15(3):165-178, doi:10.1016/j.smrv.2010.11.001

Maret S, Dorsaz S, Gurcel L, Pradervand S, Petit B, Pfister C, Hagenbuchle O, O'Hara BF, Franken P, Tafti M (2007) Homer1a is a core brain molecular correlate of sleep loss. Proc Natl Acad Sci U S A 104(50):20090-20095, doi:10.1073/pnas.0710131104

Martins PJ, Fernandes L, de Oliveira AC, Tufik S, D'Almeida V (2011) Type of diet modulates the metabolic response to sleep deprivation in rats. Nutr Metab 8(1):86, doi:10.1186/1743-7075-8-86
McEwen BS (2006) Sleep deprivation as a neurobiologic and physiologic stressor: Allostasis and allostatic load. Metab Clin Exp 55(10 Suppl 2):S20-S23, doi:10.1016/j.metabol.2006.07.008

McGlincy NJ, Valomon A, Chesham JE, Maywood ES, Hastings MH, Ule J (2012) Regulation of alternative splicing by the circadian clock and food related cues. Genome Biol 13(6):R54, doi:10.1186/gb-2012-13-6-r54

Meerlo P, Koehl M, van der Borght K, Turek FW (2002) Sleep restriction alters the hypothalamic-pituitary-adrenal response to stress. J Neuroendocrinol 14(5):397-402

Moller-Levet CS, Archer SN, Bucca G, Laing EE, Slak A, Kabiljo R, Lo JC, Santhi N, von Schantz M, Smith CP, Dijk DJ (2013) Effects of insufficient sleep on circadian rhythmicity and expression amplitude of the human blood transcriptome. Proc Natl Acad Sci U S A 110(12):E1132-E1 141, doi:10.1073/ pnas. 1217154110

Mongrain V, Hernandez SA, Pradervand S, Dorsaz S, Curie T, Hagiwara G, Gip P, Heller HC, Franken P (2010) Separating the contribution of glucocorticoids and wakefulness to the molecular and electrophysiological correlates of sleep homeostasis. Sleep 33(9):1147-1157

Mongrain V, La Spada F, Curie T, Franken P (2011) Sleep loss reduces the DNA-binding of BMAL1, CLOCK, and NPAS2 to specific clock genes in the mouse cerebral cortex. PLoS One 6(10):e26622, doi:10.1371/journal.pone.0026622

Naidoo N, Giang W, Galante RJ, Pack Al (2005) Sleep deprivation induces the unfolded protein response in mouse cerebral cortex. J Neurochem 92(5):1150-1157, doi:10.1111/j.1471-4159.2004.02952.x

Nelson SE, Duricka DL, Campbell K, Churchill L, Krueger JM (2004) Homer1a and $1 \mathrm{bc}$ levels in the rat somatosensory cortex vary with the time of day and sleep loss. Neurosci Lett 367(1):105-108, doi:10.1016/..neulet.2004.05.089

Nikonova EV, Naidoo N, Zhang L, Romer M, Cater JR, Scharf MT, Galante RJ, Pack Al (2010) Changes in components of energy regulation in mouse cortex with increases in wakefulness. Sleep 33(7):889-900

Nurminen M, Karjalainen A (2001) Epidemiologic estimate of the proportion of fatalities related to occupational factors in Finland. Scand J Work Environ Health 27(3):161-213

Petit JM, Tobler I, Kopp C, Morgenthaler F, Borbely AA, Magistretti PJ (2010) Metabolic response of the cerebral cortex following gentle sleep deprivation and modafinil administration. Sleep 33(7):901-908

Porkka-Heiskanen T, Strecker RE, Thakkar M, Bjorkum AA, Greene RW, McCarley RW (1997) Adenosine: a mediator of the sleep-inducing effects of prolonged wakefulness. Science 276(5316):1265-1268

Qureshi Al, Giles WH, Croft JB, Bliwise DL (1997) Habitual sleep patterns and risk for stroke and coronary heart disease: a 10-year follow-up from NHANES I. Neurology 48(4):904-911

Raizen DM, Zimmerman JE, Maycock MH, Ta UD, You YJ, Sundaram MV, Pack Al (2008) Lethargus is a Caenorhabditis elegans sleep-like state (vol 451, pg 569, 2008). Nature 453(7197):952-952

Rechtschaffen A, Gilliland MA, Bergmann BM, Winter JB (1983) Physiological correlates of prolonged sleep deprivation in rats. Science 221(4606):182-184

Rechtschaffen A, Bergmann BM, Gilliland MA, Bauer K (1999) Effects of method, duration, and sleep stage on rebounds from sleep deprivation in the rat. Sleep 22(1):11-31

Sabanayagam C, Shankar A (2010) Sleep duration and cardiovascular disease: results from the National Health Interview Survey. Sleep 33(8):1037-1042

Schultes B, Schmid S, Peters A, Born J, Fehm HL (2005) Sleep loss and the development of diabetes: a review of current evidence. Exp Clin Endocrinol Diabetes 113(10):563-567, doi:10.1055/s-2005-872944

Sgoifo A, Buwalda B, Roos M, Costoli T, Merati G, Meerlo P (2006) Effects of sleep deprivation on cardiac autonomic and pituitary-adrenocortical stress reactivity in rats. Psychoneuroendocrinology 31(2):197-208, doi:10.1016/j.psyneuen.2005.06.009

Shaw PJ, Cirelli C, Greenspan RJ, Tononi G (2000) Correlates of sleep and waking in Drosophila melanogaster. Science 287(5459):1834-1837

Shaw PJ, Tononi G, Greenspan RJ, Robinson DF (2002) Stress response genes protect against lethal effects of sleep deprivation in Drosophila. Nature 417(6886):287-291, doi:10.1038/417287a

Siegel JM (2005) Clues to the functions of mammalian sleep. Nature 437(7063):1264-1271, doi:10.1038/nature04285

Simons K, Toomre D (2000) Lipid rafts and signal transduction. Nat Rev Mol Cell Biol 1(1):31-39, doi:10.1038/35036052

Singh S, Amar M, Mallick BN (2012) Rapid eye movement sleep deprivation modulates Synapsinl expression in rat brain. Neurosci Lett. doi:10.1016/j. neulet.2012.05.031 
Spiegel K, Knutson K, Leproult R, Tasali E, Van Cauter E (2005) Sleep loss: a novel risk factor for insulin resistance and Type 2 diabetes. J Appl Physiol 99(5):2008-2019, doi:10.1152/japplphysiol.00660.2005

Tadavarty R, Rajput PS, Wong JM, Kumar U, Sastry BR (2011) Sleep-deprivation induces changes in GABA(B) and mGlu receptor expression and has consequences for synaptic long-term depression. PLoS One 6(9):e24933, doi:10.1371/journal.pone.0024933

Taishi P, Sanchez C, Wang Y, Fang J, Harding JW, Krueger JM (2001) Conditions that affect sleep alter the expression of molecules associated with synaptic plasticity. Am J Physiol Regul Integr 281(3):R839-R845

Terao A, Greco MA, Davis RW, Heller HC, Kilduff TS (2003a) Region-specific changes in immediate early gene expression in response to sleep deprivation and recovery sleep in the mouse brain. Neuroscience 120(4):1115-1124

Terao A, Steininger TL, Hyder K, Apte-Deshpande A, Ding J, Rishipathak D, Davis RW, Heller HC, Kilduff TS (2003b) Differential increase in the expression of heat shock protein family members during sleep deprivation and during sleep. Neuroscience 116(1):187-200

Terao A, Wisor JP, Peyron C, Apte-Deshpande A, Wurts SW, Edgar DM, Kilduff TS (2006) Gene expression in the rat brain during sleep deprivation and recovery sleep: an Affymetrix GeneChip study. Neuroscience 137(2):593-605, doi:10.1016/ j.neuroscience.2005.08.059

Thompson CL, Wisor JP, Lee CK, Pathak SD, Gerashchenko D, Smith KA, Fischer SR, Kuan CL, Sunkin SM, Ng LL, Lau C, Hawrylycz M, Jones AR, Kilduff TS, Lein ES (2010) Molecular and anatomical signatures of sleep deprivation in the mouse brain. Front Neurosci 4:165, doi:10.3389/fnins.2010.00165

Tononi G, Cirelli C (2003) Sleep and synaptic homeostasis: a hypothesis. Brain Res Bull 62(2):143-150

Van Buskirk C, Sternberg PW (2007) Epidermal growth factor signaling induces behavioral quiescence in Caenorhabditis elegans. Nat Neurosci 10(10):1300-1307, doi:10.1038/nn1981

Van Dongen HP, Maislin G, Mullington JM, Dinges DF (2003) The cumulative cost of additional wakefulness: dose-response effects on neurobehavioral functions and sleep physiology from chronic sleep restriction and total sleep deprivation. Sleep 26(2):117-126

Veasey S (2010) Sleep homeostasis: finding Odysseus among the mnesteres. Sleep 33(9):1131-1132

Volkow ND, Tomasi D, Wang GJ, Telang F, Fowler JS, Logan J, Benveniste H, Kim R, Thanos PK, Ferre S (2012) Evidence That Sleep Deprivation Downregulates Dopamine D2R in Ventral Striatum in the Human Brain. J Neurosci 32(19):6711-6717, doi:10.1523/JNEUROSCl. 0045-12.2012

Vyazovskiy W, Olcese U, Hanlon EC, Nir Y, Cirelli C, Tononi G (2011) Local sleep in awake rats. Nature 472(7344):443-447, doi:10.1038/nature10009

Wang H, Liu Y, Briesemann M, Yan J (2010) Computational analysis of gene regulation in animal sleep deprivation. Physiol Genomics 42(3):427-436, doi:10.1152/physiolgenomics.00205.2009

Weil ZM, Norman GJ, Karelina K, Morris JS, Barker JM, Su AJ, Walton JC, Bohinc S, Nelson RJ, DeVries AC (2009) Sleep deprivation attenuates inflammatory responses and ischemic cell death. Exp Neurol 218(1):129-136, doi:10.1016/j. expneurol.2009.04.018

Wisor JP, O'Hara BF, Terao A, Selby CP, Kilduff TS, Sancar A, Edgar DM, Franken P (2002) A role for cryptochromes in sleep regulation. BMC Neurosci 3:20

Wisor JP, Schmidt MA, Clegern WC (2011) Evidence for neuroinflammatory and microglial changes in the cerebral response to sleep loss. Sleep 34(3):261-272

Yokogawa T, Marin W, Faraco J, Pezeron G, Appelbaum L, Zhang J, Rosa F, Mourrain P, Mignot E (2007) Characterization of sleep in zebrafish and insomnia in hypocretin receptor mutants. PLoS Biol 5(10):2379-2397, doi:10.1371/journal.pbio.0050277

Zhdanova IV, Wang SY, Leclair OU, Danilova NP (2001) Melatonin promotes sleep-like state in zebrafish. Brain Res 903(1-2):263-268

doi:10.1186/2193-1801-3-728

Cite this article as: Elliott et al:: A review of sleep deprivation studies evaluating the brain transcriptome. SpringerPlus 2014 3:728.

\section{Submit your manuscript to a SpringerOpen ${ }^{\circ}$ journal and benefit from:}

- Convenient online submission

- Rigorous peer review

- Immediate publication on acceptance

- Open access: articles freely available online

- High visibility within the field

- Retaining the copyright to your article

Submit your next manuscript at $\gg$ springeropen.com 